\title{
Next-generation sequencing (NGS) methods and their application in clinical microbiology, infectology and epidemiology
}

\author{
(C) Viktar M. Mitsura \\ Republican Research Center for Radiation Medicine and Human Ecology, Gomel, Belarus
}

\begin{abstract}
This review presents basic principles and methods of next-generation sequencing (NGS) and discusses a number of the latest papers on the possibilities, principles and stages of NGS, as well as the application of NGS in medical research, particularly, clinical microbiology and infectious diseases, epidemiology. The development of NGS technologies will allow improving the results of diagnostics, treatment and prevention of infectious diseases and opens up new prospects for personalized medicine.
\end{abstract}

Keywords: next-generation sequencing, clinical microbiology, infectology, epidemiology.

Conflict of interests. The author declares no conflict of interests.

Funding. The study was conducted without sponsorship.

For citation: Mitsura VM. Next-generation sequencing (NGS) methods and their application in clinical microbiology, infectology and epidemiology. Health and Ecology Issues. 2021;18(4):26-32. (In Russ.). DOI: https://doi.org/10.51523/2708-6011.2021-18-4-3

\section{Методы секвенирования нового покомения (NGS) и их испомьзование в киннической микробиомогин, инфектологин и эпндемномогин}

\author{
(C) B. M. Mицура
}

Республиканский научно-практический иентр радиационной медииины и экологии человека, г. Гомель, Беларусь

\section{PEЗЮМЕ}

В обзоре представцены сведения об основных принципах и методах генного секвенирования нового поколения (next-generation sequencing, NGS). Обсуждается ряд современных работ, касающихся возможностей, принципов и этапов NGS, а также применения NGS в медицинских исследованиях, в частности: клиническая микробиология и инфекционные болезни, эпидемиология. Развитие NGS-технологий позволит улучшить результаты диагностики, цечения и профимактики инфекционных болезней и открывает новые перспективы персонализованной медицины.

Кмючевые смова: секвенирование нового поколения, клиническая микробиология, инфектология, эпидемиология.

Конфмикт интересов. Автор заявцяет об отсутствии конфцикта интересов.

Источники финансирования. Исследование проведено без спонсорской поддержки.

Дия цитирования: Мицура ВМ. Методы секвенирования нового поколения (NGS) и их использование в кцинической микробиологии, инфектологии и эпидемиологии. Проблемы здоровъя и экологии. 2021;18(4):26-32. DOI: https://doi.org/10.51523/2708-6011.2021-18-4-3

\section{Introduction}

Sequencing methods are aimed at determining the primary structure of biomacromolecules (nucleic acids, proteins and polysaccharides). Nucleic acid sequencing (DNA and RNA) allows determining the order of nucleotides in a nucleic acid sequence and to represent it in a text form. Thus, it is possible to study the sequences of regions of genes, whole genes, total messenger RNA (mRNA) and even complete genomes of organisms [1]. 
The first sequencing technologies were introduced in the late 1970s. One of the first methods was Sanger sequencing, which made it possible to determine some mutations and causes of human genetic diseases. The method allows identifying short tandem repeats and individual gene sequencing. However, it is time-consuming and allows processing only relatively short DNA sequences (up to 1,000 base pairs, bp) simultaneously. Nevertheless, the ambitious Human Genome project, completed in 2003, was carried out on the sequencers working by the Sanger method. Until now, this method is still considered the most popular and reliable [2]. Sequencing techniques have continued to progress over the past 20 years. The use of new technologies for obtaining and processing of genetic information has made it possible to significantly reduce the cost of full genome sequencing - from 10 million to 1,000 US dollars and even to 600 US dollars [3].

NGS is based on massive parallel sequencing (MPS) technology, which allows simultaneous decoding of a large number of genome regions. Up to hundreds of millions and billions of nucleotide sequences can be analyzed in one working cycle, and a distinctive feature of these methods is the multiple reading of the analyzed nucleotide sequence $[1,3]$.

\section{NGS technology: general principles}

New generation sequencing is used both to analyze the genomes of organisms for which a reference genome is already available (resequencing), and to decode the genome of an organism for the first time (de novo sequencing). These tasks are solved in different ways. For resequencing, working platforms generate a large number of short DNA fragments, which, in bioinformatic data analysis, correlate with the reference (previously sequenced) genome of a particular species. Such aligned reads can be used to search for single nucleotide polymorphisms (SNPs), small deletions and insertions, or other structural changes in the genome. Analysis of a new genome, previously unpublished (de novo sequencing) issues a more difficult challenge for the researcher to assembly single fragments into a contig, which requires numerous mathematical algorithms and massive computing power $[1,4,5]$.

The use of NGS in medical research can be roughly divided into the following groups: 1) sequencing of the entire DNA (whole-genome sequencing, WGS); 2) sequencing of the protein-coding regions of the genome (whole-exome sequencing, WES); 3) sequencing of genes of interest (from "clinical exomes", CES, which include about 5000 clinically significant genes, to small target panels analyzing 1-3 genes); 4) sequencing of the transcriptome (RNA sequencing), which is often used in oncology to classify tumors, determine neoantigens, search for new chimeric genes, etc. [5, 6].

The human genome contains approximately $3.2 \times 10^{9}$ base pairs (bp), the exome - about 20 thousand genes. Though the exome makes up about $1.5 \%$ of the entire genome, at least $80-90 \%$ of known mutations that cause various diseases occur in this area. Exome sequencing is much cheaper and easier to process, but it is rather difficult to identify large gene insertions and deletions, as well as large gene rearrangements $[5,7]$.

The steps of NGS are generally: 1) obtaining a variety of short DNA fragments or mRNA molecules and ligating of adapters; 2) amplification (multiplication) of these short sequences; 3) obtaining a DNA library (i.e., a set of DNA fragments from a studied sample) for following sequencing; 4) high-throughput reading of nucleotide sequences in this set of gene fragments. Further, the resulting data collection is processed by a computer using mathematical algorithms and compared with reference gene sequences $[1,4,7,8]$.

Genomic sequencers (devices used for sequencing) for research and applied projects are produced by various manufacturers, of which the most widely represented are Illumina, Thermo Fisher Scientific, Oxford Nanopore Technologies, Pacific Biosciences and others [3, 4]. They differ in their technical characteristics. Conventionally, the performance of these devices can be compared in terms of the sequencing output (the total size of generated sequence data), which is measured in million or billion bp $(\mathrm{Mb}, \mathrm{Gb})$ for a certain time. It should be noted that the range of sequencing instruments is not limited to the presented instruments and is being improved rapidly. New manufacturers are currently entering the sequencer market, including BGI (China, www.bgi.com), Nebula Genomics (USA, https://nebula.org), Axbio (USA, China, www.axbio.cn) and others. Newly developed sequencing techniques, including those based on other technologies, make it possible to achieve miniaturization, automation, greater instrument productivity and lower cost of the process $[9,10,11]$.

\section{Clinical microbiology and infectious diseases}

Globally, infectious diseases remain one of the most significant causes of morbidity and 
mortality. Correct and accurate etiologic diagnosis is critical for patient management, since delayed or incorrect diagnosis can lead to many side effects, including unnecessary or inappropriate use of antibiotics, increased health care costs, and decreased patient outcomes [12].

Traditional laboratory diagnostic methods such as culture-based or PCR tests are generally reliable and cost-effective for common pathogens; nevertheless, NGS can be of great importance in cases where a priori information about the pathogen is not available. In many cases, rapid detection of the pathogen and associated markers of resistance or virulence is extremely important for proper and timely treatment $[12,13]$.

There are three main types of NGS techniques used in clinical microbiology [3]. The first type includes targeted NGS panels, which are designed to screen clinical isolates for a known set of possible pathogens. The panels can be specific or target several types of pathogens, including bacteria, viruses, and even eukaryotic organisms. These panels can also be optimized for use with specific sample types such as cerebrospinal fluid. The advantages of these panels are their high specificity, sensitivity, fast processing times, and the ability to sequence directly from a clinical sample. However, the disadvantages include their limited assortment and inability to identify new pathogens or markers of antibiotic resistance $[3,14]$.

The second type of methods is genome-wide sequencing of bacterial samples, which allows examining the entire genome of a pathogen, including plasmids. This broad sequencing allows the identification of antibiotic resistance profiles that can be used to make decisions about the use of first-line drugs. The disadvantage of this approach is that a separate culture step is usually required to ensure that the sample does not contain other contaminating or commensal bacteria. However, sequencing directly from a clinical isolate without a culture step is possible if targeted enrichment is applied. Moreover, although genome-wide sequencing datasets accurately identify known markers of drug resistance, the discovery of new mutations and their effect on the phenotype add additional uncertainty into the test [15].

The third type of method is metagenomic NGS (mNGS), which can use samples obtained directly from the patient and amplify the nucleotide sequences of all organisms in the sample, including the host cells. This approach allows the detection of several types of pathogens in a single sample (and even the body's response to them) and can be especially useful when targeted or less comprehensive tests are not diagnostic. In addition, mNGS can detect pathogen sequences that represent a very small fraction of all sequenced reads; such low-level sequences can be easily missed by other methods. mNGS had a higher sensitivity than culturing while studying blood, bronchoalveolar lavage and sputum samples, as was shown for Klebsiella, CMV and EBV [16]. However, using the mNGS approach has significant limitations: the cost and complexity of the process, as well as the need to optimize and standardize each step in the test, from sample preparation to data analysis. Results can be skewed by the presence of host DNA / RNA, and commensal bacteria in samples and contaminated laboratory reagents can also make testing difficult leading to incorrect results $[3,17]$.

NGS is particularly useful in situations where results are delayed or the culture method is not diagnostic, and can detect markers of antimicrobial resistance or virulence at a low frequency, while exhibiting sensitivity and specificity comparable to standard practice. NGS can also bridge the gap between culture-based and molecular-based diagnostic routine and identify multiple co-infections that can skew routine test results $[8,13]$. In addition, culturing may be less effective as a diagnostic test when used to detect pathogens in patients who have already received antibiotics. In one study, NGS showed significantly higher sensitivity than culture methods in patients previously exposed to antibiotics [18]. Finally, NGS using extracellular DNA in the urine or blood has been shown to be effective in diagnosing additional pathogens when culture-based methods have failed [19].

\section{Public health and epidemiology}

NGS has shown its effectiveness in the identification of the etiology of infectious disease outbreaks. In particular, in 2015, during the outbreak of Ebola fever in West Africa, a field laboratory equipped with a MinION sequencer was able to process more than 140 virus samples, and the time to obtain the result did not exceed a day [3]. Just several days after the outbreak of new coronavirus-related pneumonia in Wuhan, China, the new coronavirus, SARS-CoV-2, was sequenced using mNGS, which has served to diagnose and monitor the spread of the disease, and to develop effective antiviral drugs and preventive vaccines [20]. In addition, NGS has proven its value in monitoring the most common influenza strains, which 
has an important impact on the development of annual vaccines [21].

NGS has also helped to track disease outbreaks in the clinical setting, especially in cases of health-care acquired infections. WGS allows microbial typing, which is used for epidemiological investigations. This is especially important for identifying outbreaks and monitoring the evolution of multidrug-resistant pathogens. For example, the study of multidrug-resistant strains of $\mathrm{K}$. pneumoniae, using genomic phylogenetic analysis, made it possible to trace the transmission of bacteria between patients treated in the same center in the Netherlands, and the subsequent spread in the hospital [13].

Molecular epidemiology is now an established branch of epidemiology developed by merging molecular biology into epidemiological studies. It is a discipline that uses molecular microbiology principles to study the distribution and determining factors of infectious diseases in human populations. Molecular epidemiology, by definition, is laboratory-based, and the NGS technology is now the main tool for molecular epidemiologic investigations [22, 23].

More and more attention is being paid to the microbiome of the human body; its relationship with various somatic and even mental disorders has been proven. Using datasets about the host's microbiome, as well as changes in host gene expression, can significantly increase the predictive value of testing [24]. One study on lower respiratory tract infections showed that an approach combining the expression signature of the patient's immune response genes as measured by profiling the host transcriptome through RNA sequencing, along with mNGS to identify and distinguish between the patient's own commensal flora and the genomes of pathogens, was useful for accurate identification of the pathogen and achievement of high sensitivity and specificity with a truly negative predictive value of $100 \%$ [25]. Virome sequencing in immunocompromised patients after organ or stem cell transplantation can assess the competence of the host's immune system, since viral load may increase with the use of immunosuppressive drugs [26]. Changes in the diversity of the commensal bacterial flora may indicate the onset or progression of the disease [27]. The increase in this diversity in patients with Clostridium difficile infections who received substitution treatment (fecal transplant) also was controlled by NGS [28].

The method of the characterization of bacterial communities in terms of species composition with the use of NGS was proposed recently by A. Rapin et al. The method allows predicting the composition of the entire bacterial community and includes extracting the entire DNA content of a microbiota sample and performing a targeted high-throughput sequencing of the 16S rRNA gene [29].

\section{Conclusion}

It is assumed that genomic sequencing will play an increasingly important role in clinical medicine, solving an increasing number of diagnostic and therapeutic problems. However, there are still unresolved issues in the analysis, interpretation and data storage. The implementation of NGS tests in clinical diagnostic laboratories requires significant resources, which is often expensive for most small laboratories.

NGS is a revolutionary technology that opens up new possibilities for molecular diagnostics. Many clinical laboratories have already implemented NGS methods to detect pathogens and their drug resistance in infectious diseases, to control the host's immune response to infection and to study microbiome changes in different conditions.

Overall, further advances in sequencing technologies will boost new opportunities for integrating sequencing data from both host and pathogens in order to provide a more personalized and holistic approach to clinical patient management.

\section{References}

1. Yohe S, Thyagarajan B. Review of clinical next-generation sequencing. Arch Pathol Lab Med. 2017;141(11):1544-1557.

DOI: https://doi.org/ 10.5858/arpa.2016-0501-RA

2. Heather JM, Chain B. The sequence of sequencers: The history of sequencing DNA. Genomics. 2016;107(1):1-8. DOI: https://doi.org/10.1016/j.ygeno.2015.11.003

3. Zhong Y, Xu F, Wu J, Schubert J, Li MM. Application of next generation sequencing in laboratory medicine. Ann Lab Med. 2021;41(1):25-43.

DOI: https://doi.org/10.3343/alm.2021.41.1.25
4. McCombie WR, McPherson JD, Mardis ER. NextGeneration Sequencing Technologies. Cold Spring Harb Perspect Med. 2019;9(11):a036798.

DOI: https://doi.org/10.1101/cshperspect.a036798

5. Petersen BS, Fredrich B, Hoeppner MP, Ellinghaus D, Franke A. Opportunities and challenges of whole-genome and -exome sequencing. BMC Genet. 2017;18(1):14. DOI: https://doi.org/10.1186/s12863-017-0479-5

6. Hayeems RZ, Dimmock D, Bick D, Belmont JW, Green RC, Lanpher B, Jobanputra V, Mendoza R, Kulkarni Sh, Grove ME, Taylor SL, Ashley E, Medical 
Genome Initiative. Clinical utility of genomic sequencing: a measurement toolkit. Genomic Medicine. 2020;5:56. DOI: https://doi.org/10.1038/s41525-020-00164-7

7. Prokop JW, May T, Strong K, Bilinovich SM, Bupp C, Rajasekaran S, Worthey EA, Lazar J. Genome sequencing in the clinic: the past, present, and future of genomic medicine. Physiol Genomics. 2018 Aug 1;50(8):563-579. DOI: https://doi.org/10.1152/physiolgenomics.00046.2018 8. Vincent AT, Derome N, Boyle B, Culley AI, Charette SJ. Next-generation sequencing (NGS) in the microbiological world: How to make the most of your money. J Microbiol Methods. 2017;138:60-71. DOI: https://doi.org/10.1016/j.mimet.2016.02.016

9. Besser J, Carleton HA, Gerner-Smidt P, Lindsey RL, Trees E. Next-generation sequencing technologies and their application to the study and control of bacterial infections. Clin Microbiol Infect. 2018;24(4):335-341.

DOI: https://doi.org/10.1016/j.cmi.2017.10.013

10. Xu Y, Lin Z, Tang C, Tang Y, Cai Y, Zhong H, Wang X, Zhang W, Xu C, Wang J, Wang J, Yang H, Yang L, Gao Q. A new massively parallel nanoball sequencing platform for whole exome research. BMC Bioinformatics. 2019;20(1):153.

DOI: https://doi.org/10.1186/s12859-019-2751-3

11. Natarajan $\mathrm{KN}$, Miao $\mathrm{Zh}$, Jiang $\mathrm{M}$, Huang $\mathrm{X}$, Zhou H, Xie J, Wang Ch, et al. Comparative analysis of sequencing technologies for single-cell transcriptomics. Genome Biol. 2019;20:70.

DOI: https://doi.org/10.1186/s13059-019-1676-5

12. Esposito S. Infectious Diseases: Pathophysiology, Diagnostics and Prevention. Int J Mol Sci. 2016;17(9):1464. DOI: https://doi.org/10.3390/ijms 17091464

13. Deurenberg RH, Bathoorn E, Chlebowicz MA Couto N, Ferdous M, García-Cobos S, Kooistra-Smid AM, Raangs EC, Rosema S, Veloo AC, Zhou K, Friedrich AW, Rossen JW. Application of next generation sequencing in clinical microbiology and infection prevention. J Biotechnol. 2017;243:16-24.

DOI: https://doi.org/10.1016/j.jbiotec.2016.12.022

14. Leber AL, Everhart K, Balada-Llasat JM, Cullison J, Daly J, Holt S, Lephart P, Salimnia H, Schreckenberger PC, DesJarlais S, Reed SL, Chapin KC, LeBlanc L, Johnson JK, Soliven NL, Carroll KC, Miller JA, Dien Bard J, Mestas J, Bankowski M, Enomoto T, Hemmert AC, Bourzac KM. Multicenter Evaluation of BioFire FilmArray Meningitis/ Encephalitis Panel for Detection of Bacteria, Viruses, and Yeast in Cerebrospinal Fluid Specimens. J Clin Microbiol. 2016;54(9):2251-2261.

DOI: https://doi.org/10.1128/JCM.00730-16

15. Ellington MJ, Ekelund O, Aarestrup FM, Canton R, Doumith M, Giske C, Grundman H, Hasman H, Holden MTG, Hopkins KL, Iredell J, Kahlmeter G, Köser CU, MacGowan A, Mevius D, Mulvey M, Naas T, Peto T, Rolain JM, Samuelsen $\varnothing$, Woodford N. The role of whole genome sequencing in antimicrobial susceptibility testing of bacteria: report from the EUCAST Subcommittee. Clin Microbiol Infect. 2017;23(1):2-22.

DOI: https://doi.org/10.1016/j.cmi.2016.11.012

16. Duan H, Li X, Mei A, Li P, Liu Y, Li X, Li W, Wang $\mathrm{C}$, Xie S. The diagnostic value of metagenomic nextgeneration sequencing in infectious diseases. BMC Infect. Dis. 2021;21 (1):62.

DOI: https://doi.org/10.1186/s12879-020-05746-5

17. Chiu CY, Miller SA. Clinical metagenomics. Nature Rev Genetics. 2019;20(6):341-355.

DOI: https://doi.org/10.1038/s41576-019-0113-7
18. Miao Q, Ma Y, Wang Q, Pan J, Zhang Y, Jin W, Yao Y, Su Y, Huang Y, Wang M, Li B, Li H, Zhou C, Li C, Ye M, Xu X, Li Y, Hu B. Microbiological diagnostic performance of metagenomic next-generation sequencing when applied to clinical Practice. Clin Infect Dis. 2018;67:S231-40.

DOI: https://doi.org/10.1093/cid/ciy693

19. Yu X, Jiang W, Shi Y, Ye H, Lin J. Application of sequencing technology in clinical microbial infection. J Cell Mol Med. 2019;23(11):7143-7150.

DOI: https://doi.org/10.1111/jcmm.14624

20. Zhou $\mathrm{P}$, Yang $\mathrm{XL}$, Wang $\mathrm{XG}$, Hu $\mathrm{B}$, Zhang $\mathrm{L}$, Zhang W, Si HR, Zhu Y, Li B, Huang CL, Chen HD, Chen J, Luo Y, Guo H, Jiang RD, Liu MQ, Chen Y, Shen XR, Wang X, Zheng XS, Zhao K, Chen QJ, Deng F, Liu LL, Yan B, Zhan FX, Wang YY, Xiao GF, Shi ZL. A pneumonia outbreak associated with a new coronavirus of probable bat origin. Nature. 2020;579(7798):270-273.

DOI: https://doi.org/10.1038/s41586-020-2012-7

21. Gwinn M, MacCannell DR, Khabbaz RF. Integrating advanced molecular technologies into public health. J Clin Microbiol. 2017;55(3):703-714.

DOI: https://doi.org/10.1128/JCM.01967-16

22. Riley LW, Blanton RE. Advances in Molecular Epidemiology of Infectious Diseases: Definitions, Approaches, and Scope of the Field. Microbiol Spectr. 2018;6(6):10.1128/microbiolspec.AME-0001-2018.

DOI: https://doi.org/10.1128/microbiolspec.AME-0001-2018

23. Eybpoosh S, Haghdoost AA, Mostafavi E, Bahrampour A, Azadmanesh K, Zolala F. Molecular epidemiology of infectious diseases. Electron Physician. 2017;9(8):5149-5158.

DOI: https://doi.org/10.19082/5149

24. Stoma IO, Karpov IA. Human microbiome. Minsk, Doctor-Design; 2018. 120 p. (In Russ.).

25. Langelier C, Kalantar KL, Moazed F, Wilson MR, Crawford ED, Deiss T, et al. Integrating host response and unbiased microbe detection for lower respiratory tract infection diagnosis in critically ill adults. Proc Natl Acad Sci USA 2018;115:E12353-E62.

DOI: https://doi.org/10.1073/pnas. 1809700115

26. De Vlaminck I, Khush KK, Strehl C, Kohli B, Neff NF, Okamoto J, Snyder TM, Weill D, Bernstein D, Valantine HA, Quake SR. Temporal response of the human virome to immunosuppression and antiviral therapy. Cell 2013;155(5):1178-1187.

DOI: https://doi.org/10.1016/j.cell.2013.10.034

27. Morgan XC, Tickle TL, Sokol H, Gevers D, Devaney KL, Ward DV, Reyes JA, Shah SA, LeLeiko N, Snapper SB, Bousvaros A, Korzenik J, Sands BE, Xavier RJ, Huttenhower C. Dysfunction of the intestinal microbiome in inflammatory bowel disease and treatment. Genome Biol. 2012;13:R79. DOI: https://doi.org/10.1186/gb-2012-13-9-r79

28. van Nood E, Vrieze A, Nieuwdorp M, Fuentes S, Zoetendal EG, de Vos WM, Visser CE, Kuijper EJ, Joep Bartelsman FWM, Tijssen JGP, Speelman P, Dijkgraaf MGW, Keller JJ. Duodenal infusion of donor feces for recurrent Clostridium difficile. N Engl J Med. 2013;368:407-15. DOI: https://doi.org/10.1056/NEJMoa1205037

29. Rapin A, Pattaroni C, Marsland BJ, Harris NL. Microbiota Analysis Using an Illumina MiSeq Platform to Sequence 16S rRNA Genes. Curr Protoc Mouse Biol. 2017;7(2):100-129.

DOI: https://doi.org/10.1002/cpmo.29

\section{Cписок питературы}

1. Yohe S, Thyagarajan B. Review of clinical next-generation sequencing. Arch Pathol Lab Med. 2017;141(11):1544-1557.

DOI: https://doi.org/10.5858/arpa.2016-0501-RA
2. Heather JM, Chain B. The sequence of sequencers: The history of sequencing DNA. Genomics. 2016;107(1):1-8. DOI: https://doi.org/10.1016/j.ygeno.2015.11.003 
3. Zhong Y, Xu F, Wu J, Schubert J, Li MM. Application of next generation sequencing in laboratory medicine. Ann Lab Med. 2021;41(1):25-43.

DOI: https://doi.org/10.3343/alm.2021.41.1.25

4. McCombie WR, McPherson JD, Mardis ER. Next-Generation Sequencing Technologies. Cold Spring Harb Perspect Med. 2019;9(11):a036798.

DOI: https://doi.org/10.1101/cshperspect.a036798

5. Petersen BS, Fredrich B, Hoeppner MP, Ellinghaus D, Franke A. Opportunities and challenges of whole-genome and -exome sequencing. BMC Genet. 2017;18(1):14. DOI: https://doi.org/10.1186/s12863-017-0479-5

6. Hayeems RZ, Dimmock D, Bick D, Belmont JW, Green RC, Lanpher B, Jobanputra V, Mendoza R, Kulkarni Sh, Grove ME, Taylor SL, Ashley E, Medical Genome Initiative. Clinical utility of genomic sequencing: a measurement toolkit. Genomic Medicine. 2020;5:56.

DOI: https://doi.org/10.1038/s41525-020-00164-7

7. Prokop JW, May T, Strong K, Bilinovich SM, Bupp C, Rajasekaran S, Worthey EA, Lazar J. Genome sequencing in the clinic: the past, present, and future of genomic medicine. Physiol Genomics. 2018 Aug 1;50(8):563-579. DOI: https://doi.org/ 10.1152/physiolgenomics.00046.2018

8. Vincent AT, Derome N, Boyle B, Culley AI, Charette SJ. Next-generation sequencing (NGS) in the microbiological world: How to make the most of your money. J Microbiol Methods. 2017;138:60-71.

DOI: https://doi.org/10.1016/j.mimet.2016.02.016

9. Besser J, Carleton HA, Gerner-Smidt P, Lindsey RL, Trees E. Next-generation sequencing technologies and their application to the study and control of bacterial infections. Clin Microbiol Infect. 2018;24(4):335-341.

DOI: https://doi.org/10.1016/j.cmi.2017.10.013

10. Xu Y, Lin $Z$, Tang $C$, Tang $Y$, Cai $Y$, Zhong $H$, Wang X, Zhang W, Xu C, Wang J, Wang J, Yang H, Yang L, Gao Q. A new massively parallel nanoball sequencing platform for whole exome research. BMC Bioinformatics. 2019;20(1):153.

DOI: https://doi.org/10.1186/s12859-019-2751-3

11. Natarajan KN, Miao Zh, Jiang M, Huang X, Zhou $\mathrm{H}$, Xie J, Wang Ch, et al. Comparative analysis of sequencing technologies for single-cell transcriptomics. Genome Biol. 2019;20:70.

DOI: https://doi.org/10.1186/s13059-019-1676-5

12. Esposito S. Infectious Diseases: Pathophysiology, Diagnostics and Prevention. Int J Mol Sci. 2016;17(9):1464. DOI: https://doi.org/10.3390/ijms 17091464

13. Deurenberg RH, Bathoorn E, Chlebowicz MA, Couto N, Ferdous M, García-Cobos S, Kooistra-Smid AM, Raangs EC, Rosema S, Veloo AC, Zhou K, Friedrich AW, Rossen JW. Application of next generation sequencing in clinical microbiology and infection prevention. J Biotechnol. 2017;243:16-24.

DOI: https://doi.org/10.1016/j.jbiotec.2016.12.022

14. Leber AL, Everhart K, Balada-Llasat JM, Cullison J, Daly J, Holt S, Lephart P, Salimnia H, Schreckenberger PC, DesJarlais S, Reed SL, Chapin KC, LeBlanc L, Johnson JK, Soliven NL, Carroll KC, Miller JA, Dien Bard J, Mestas J, Bankowski M, Enomoto T, Hemmert AC, Bourzac KM. Multicenter Evaluation of BioFire FilmArray Meningitis/Encephalitis Panel for Detection of Bacteria, Viruses, and Yeast in Cerebrospinal Fluid Specimens. J Clin Microbiol. 2016;54(9):2251-2261. DOI: https://doi.org/10.1128/JCM.00730-16

15. Ellington MJ, Ekelund O, Aarestrup FM, Canton R, Doumith M, Giske C, Grundman H, Hasman H, Holden MTG, Hopkins KL, Iredell J, Kahlmeter G, Köser CU, MacGowan A, Mevius D, Mulvey M, Naas T, Peto T, Rolain JM, Samuelsen $\varnothing$, Woodford N. The role of whole genome sequencing in antimicrobial susceptibility testing of bacteria: report from the EUCAST Subcommittee. Clin Microbiol Infect. 2017;23(1):2-22.

DOI: https://doi.org/10.1016/j.cmi.2016.11.012
16. Duan H, Li X, Mei A, Li P, Liu Y, Li X, Li W, Wang $\mathrm{C}$, Xie S. The diagnostic value of metagenomic next-generation sequencing in infectious diseases. BMC Infect Dis. 2021;21(1):62.

DOI: https://doi.org/10.1186/s12879-020-05746-5

17. Chiu CY, Miller SA. Clinical metagenomics. $\mathrm{Na}$ ture Rev Genetics. 2019;20(6):341-355.

DOI: https://doi.org/10.1038/s41576-019-0113-7

18. Miao Q, Ma Y, Wang Q, Pan J, Zhang Y, Jin W, Yao Y, Su Y, Huang Y, Wang M, Li B, Li H, Zhou C, Li C, Ye M, Xu X, Li Y, Hu B. Microbiological diagnostic performance of metagenomic next-generation sequencing when applied to clinical Practice. Clin Infect Dis. 2018;67:S231-240. DOI: https://doi.org/10.1093/cid/ciy693

19. Yu X, Jiang W, Shi Y, Ye H, Lin J. Application of sequencing technology in clinical microbial infection. $J$ Cell Mol Med. 2019;23(11):7143-7150.

DOI: https://doi.org/10.1111/jcmm.14624

20. Zhou $\mathrm{P}$, Yang $\mathrm{XL}$, Wang $\mathrm{XG}$, Hu B, Zhang L, Zhang W, Si HR, Zhu Y, Li B, Huang CL, Chen HD, Chen J, Luo Y, Guo H, Jiang RD, Liu MQ, Chen Y, Shen XR, Wang X, Zheng XS, Zhao K, Chen QJ, Deng F, Liu LL, Yan B, Zhan FX, Wang YY, Xiao GF, Shi ZL. A pneumonia outbreak associated with a new coronavirus of probable bat origin. Nature. 2020;579(7798):270-273.

DOI: https://doi.org/10.1038/s41586-020-2012-7

21. Gwinn M, MacCannell DR, Khabbaz RF. Integrating advanced molecular technologies into public health. $J$ Clin Microbiol. 2017;55(3):703-714.

DOI: https://doi.org/10.1128/JCM.01967-16

22. Riley LW, Blanton RE. Advances in Molecular Epidemiology of Infectious Diseases: Definitions, Approaches, and Scope of the Field. Microbiol Spectr. 2018;6(6):10.1128/ microbiolspec.AME-0001-2018.

DOI: https://doi.org/10.1128/microbiolspec.AME-0001-2018

23. Eybpoosh S, Haghdoost AA, Mostafavi E, Bahrampour A, Azadmanesh K, Zolala F. Molecular epidemiology of infectious diseases. Electron Physician. 2017;9(8):51495158.

DOI: https://doi.org/10.19082/5149

24. Стома ИО, Карпов ИА. Микробиом человека. Минск: Доктор-Дизайн, 2018. 120 с.

25. Langelier C, Kalantar KL, Moazed F, Wilson MR, Crawford ED, Deiss T, et al. Integrating host response and unbiased microbe detection for lower respiratory tract infection diagnosis in critically ill adults. Proc Natl Acad Sci USA 2018;115:E12353-E62.

DOI: https://doi.org/10.1073/pnas. 1809700115

26. De Vlaminck I, Khush KK, Strehl C, Kohli B, Neff NF, Okamoto J, Snyder TM, Weill D, Bernstein D, Valantine HA, Quake SR. Temporal response of the human virome to immunosuppression and antiviral therapy. Cell 2013;155(5):1178-1187.

DOI: https://doi.org/10.1016/j.cell.2013.10.034

27. Morgan XC, Tickle TL, Sokol H, Gevers D, Devaney KL, Ward DV, Reyes JA, Shah SA, LeLeiko N, Snapper SB, Bousvaros A, Korzenik J, Sands BE, Xavier RJ, Huttenhower C. Dysfunction of the intestinal microbiome in inflammatory bowel disease and treatment. Genome Biol. 2012;13:R79.

DOI: https://doi.org/10.1186/gb-2012-13-9-r79

28. van Nood E, Vrieze A, Nieuwdorp M, Fuentes S, Zoetendal EG, de Vos WM, Visser CE, Kuijper EJ, Joep Bartelsman FWM, Tijssen JGP, Speelman P, Dijkgraaf MGW, Keller JJ. Duodenal infusion of donor feces for recurrent Clostridium difficile. $N$ Engl J Med. 2013;368:407-415.

DOI: https://doi.org/10.1056/NEJMoa1205037

29. Rapin A, Pattaroni C, Marsland BJ, Harris NL. Microbiota Analysis Using an Illumina MiSeq Platform to Sequence 16S rRNA Genes. Curr Protoc Mouse Biol. 2017;7(2):100-129.

DOI: https://doi.org/10.1002/cpmo.29 


\section{Information about the author / Информация об авторе}

Viktar M. Mitsura, DMedSc, Associate Professor, Deputy Director for Research, Republican Research Center for Radiation Medicine and Human Ecology,

Gomel, Belarus; Professor at the Department of Infectious Diseases, Gomel State Medical University, Gomel, Belarus

ORCID: https://orcid.org/0000-0002-0449-5026 e-mail: mitsura_victor@tut.by
Мицура Виктор Михайлович, д.м.н., доцент, заместитель директора по научной работе, ГУ "Республиканский научно-практический центр радиационной медицины и экологии чемовека»; профессор кафедры инфекционных болезней, УО «Гомельский государственный медицинский университет"

ORCID: https://orcid.org/0000-0002-0449-5026 e-mail: mitsura_victor@tut.by

\section{Corresponding author / Автор, ответственный за переписку}

Viktar M. Mitsura

e-mail: mitsura_victor@tut.by
Мицура Виктор Михайлович

e-mail: mitsura_victor@tut.by

Received / Поступила в редакиию 18.07.2021

Revised / Поступила после реиензирования 05.10.2021

Accepted / Принята к публикаиии 29.12.2021 